\title{
コンクリート円柱のフープ筋による拘束効果の解析 ANALYSIS OF CONCRETE CONFINEMENT BY CIRCULAR HOOPS
}

\author{
小椋 紀 行*, 市之瀬 敏勝** \\ Noriyuki OGURA and Toshikatsu ICHINOSE
}

\begin{abstract}
Confining effect of concrete pillar by circular hoops is analyzed assuming as follow.
1) Mohr's theory of failure is applicable to concrete under triaxial compression.

2) Stress field is given by functions so that principal stresses distribute like an onion with a core.

The equilibrium conditions are considered approximately, but not rigorously. Thus, imaginary body forces are assumed to satisfy the conditions. The functions of principal stresses are determined so that the imaginary body forces are minimized. According to the lower bound theorem, the maximum strength may be chosen as the strength of a pillar.

The pillar strength decreases as the hoop spacing increase, even if shear reinforcement ratio is the same. This tendency agrees with existing experimental results quantitatively.
\end{abstract}

Keywords : circular hoop, confining effect, triaxial compression, imaginary body force, the lower bound theorem

円形フープ筋、拘束効果，三跂圧縓，仮想物体力，下界完理

\section{1. 序論}

コンクリート円柱の円形フープ箭による拘束效果は， 能動的拘束と受動的拘束の 2 種類に大別できる。

能秒的拘束とは。清水压機などによって機械的にコン クリートに加えられる肳柬のことである。この拘来は任 意に变化させることが出来るため，三軘压繀応力下での コンクリートの材料特怆などを調べるためによく用いら れる。

また、受動的哬束とは、フープ䈈などが配箱されたコ ンクリートが軹方向に压綰力を受けた場合．コンクリー

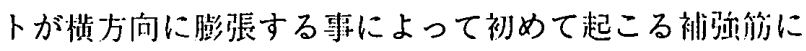
よる拘束のことである。そのためコンクリートの杣ひず みが小さい時はこの拘束は小さく，籼ひずみが大きくな るに従って拘束力も大きくなる。

この受哑的拘束による効果について、鈴木・中挥らの

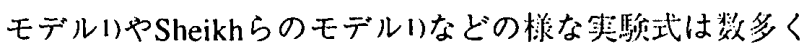
提案されている。しかし，この拘束效果を解析的に求め
ている研究は少ない。本論では，この受動的拘束の効果 について下界完理を用い三軸圧縮によるコンクリートの 沙度上暴を考虛に入れた解析を行った。

\section{2. 解析仮定}

2.1 仮定 1 : 破壊条件

三杣圧樎を受けるコンクリートは，Richartら3)の静水 正下での実験式（つまり，Mohr-Coulombの破壊基準）で ある以下の式（1）を満たすとき破壊すると仮定する。

$$
\sigma_{3}=m \sigma_{1}+\sigma_{B}
$$

$\sigma_{1}:$ コンクリートの第 1 (最小) 主応力

の3:コンクリートの第 3（最大）主応力

$\mathrm{m}$ : 奏験より得られる倸数（本論文においては $\mathrm{m}=4.1$ )

$\sigma_{\mathrm{B}}$ : 焎筋コンクリートの一軸圧縮強度

（以下压縮を正とする。）
* 名古屋工業大学社会開発工学科 大学院生. 工修

** 名古屋工業大学社会開発工学科 助教授. 工博
Graduate Student, Dept. of Architecture, Nagoya Institute of Technology, M. Eng.

Associate Prof., Dept. of Architecture, Nagoya Institute of Technology, Dr. Eng. 


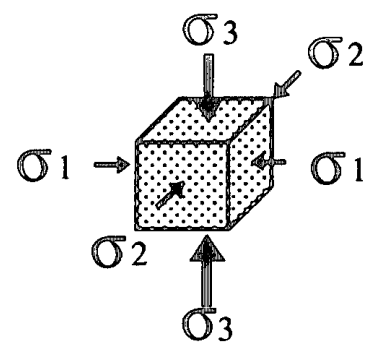

図 1 三軸圧縮

\section{2 仮管 2 ：压䋧応力場}

压樎応力場は図 2 の㥞に鼓が積み重なったような形で 存在すると仮完する。この図において、Dはコンクリー ト円柱の直径，sは補少筋間隔である。また，図に示す ように $\mathrm{r}$ 軸、 $\mathrm{z}$ 軸、 $\theta$ 糨をとる。具体的には压繀応力場 は，図 3 に示すように中央にある円筒形状の部分とその 回りにあるタマネギ状の部分とフープ筋付近の支压部分 からなる。本論文ではこれらの応力場を顼にコア湖。 オニオン部，支压部と称する。この図においてd゙はフー プ筋の直径を示す。さらに，解析を簡略化するために図 4. 5 に示すように前述の 2 つの応力場（コア部。オ二 オン部）のみに置き撸えて解析を行う。(この詳細につ

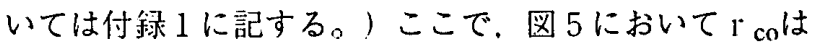

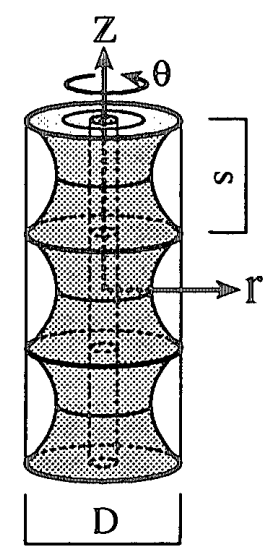

図 2 圧縮応力場

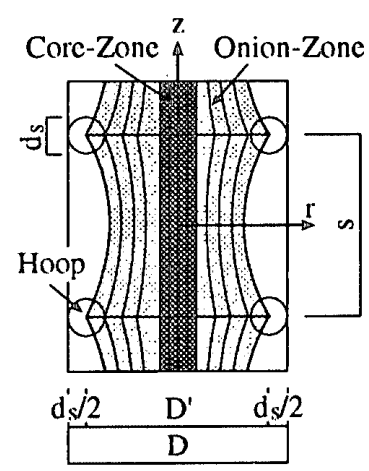

図4 㐫力場断面図 2

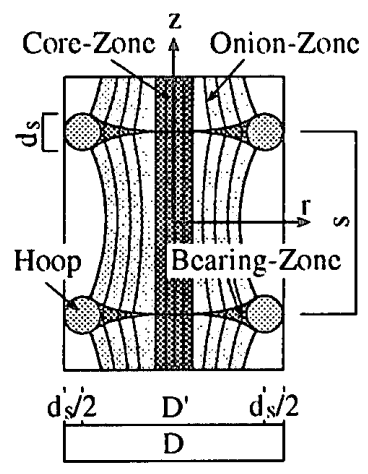

図 3 応力場断面図 1

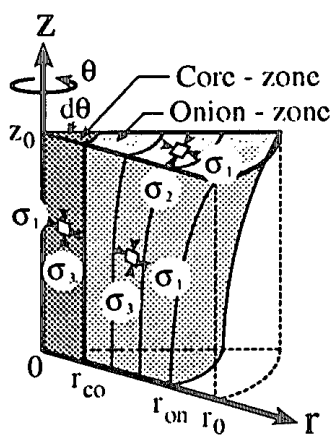

図 5 応力場詳細図

コア部の半径, $\mathrm{r}_{\mathrm{on}}$ はオニオン部の半径, $\mathrm{r}_{0}$ は $\mathrm{D}^{\prime} / 2, z_{0}$ はs/2である。

\section{2 .1 第 3 主応力の軌跡の仮定}

第 3 主応力 $\sigma_{3}$ の軌跡は図 6 に示す様な関数式 $\mathrm{J}(\mathrm{r}, \mathrm{z})$ を用いて表す。 $\mathbf{J}(\mathbf{r}, \mathbf{z})$ は，コア部では式（2）に示すよ うに単に=rと仮定し、オニオン部では式（3）に示す ように $\mathrm{r}$ に関して 1 次関数であり $z$ に関して 2 次関数で 仮倇する。

$$
\begin{array}{ll}
J(r, z)=r & \left(0 \leq r \leq r_{c o}\right) \\
J(r, z)=a\left(r-r_{c o}\right) z^{2}+r & \left(r_{c o} \leq r \leq r_{o n}\right)
\end{array}
$$

ここで境界条件 $\mathrm{J}\left(\mathrm{r}_{\mathrm{on}}, \mathrm{z}_{0}\right)=\mathrm{r}_{0}$ より，式（3）におけ る完数 aは以下の式 (4) により得られる。

$$
a=\frac{r_{0}-r_{o n}}{\left(r_{o n}-r_{c o}\right) z_{0}^{2}}
$$

また，主応力の方向 $\phi(r, z)$ は式（5）で得られる。

$$
\tan \phi(r, z)=\frac{\partial}{\partial z} J(r, z)
$$

\section{2 .2 第 1 主応力の仮定}

図 7 に座標 $(\mathrm{J}(\mathrm{r}, \mathrm{z}), \mathrm{z})$ における第1主応力 $\sigma_{1}(\mathrm{r}, \mathrm{z})$ の分布を表す。コア部での第 1 主応力 $\sigma 1$ は式（6）に示 す㥞に係数 《1を用いた定数で仮定する。オニオン部にお いては式（7）に示すようなとに関して 2 次関数であ $\eta 、 z$ に関しては 1 次関数となる様に係数 $\alpha_{1}$ と $\alpha_{2}$ を用 いて仮定する。

$$
\begin{array}{r}
\sigma_{1}(r, z)=\alpha_{1}\left(r_{c o}-r_{o n}\right) \quad\left(0 \leq r \leq r_{c o}\right) \\
\sigma_{1}(r, z)=\left\{\alpha_{1}+\alpha_{2}\left(z_{0}-z\right)\left(r-r_{c o}\right)\right\}\left(r-r_{o n}\right) \\
\left(r_{c o} \leq r \leq r_{o n}\right)
\end{array}
$$

上式（6)（7）は圧縮応力場の最外面において $\sigma_{l}(\mathrm{r}, \mathrm{z})$ は0という境界条件を満たす。

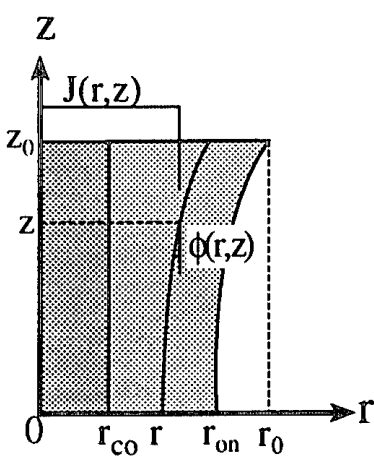

図 $6 \quad \sigma_{3}$ の軌跡

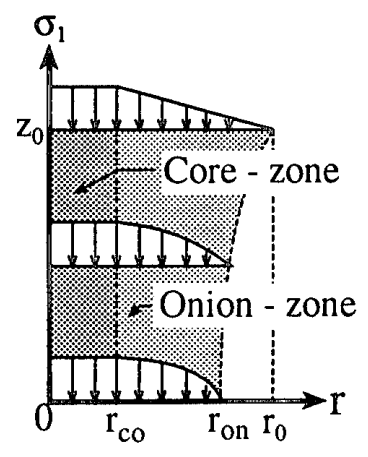

図 $7 \sigma$,の分布 


\section{2 .3 第 2.3 主応力}

第 2 主応力。 $2(\mathrm{r}, \mathrm{z})$ は，下界定理より第 1 主応力に等 しくなる。第 3 主応力。 $3(\mathrm{r}, \mathrm{z})$ は仮定 1 より式 (1) で 得られる。

\section{3. 解析方法}

3.1 釣合条件

図8に示すような压縮応力場内の微小立休を䏘いて，

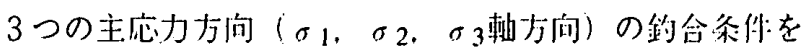
考える。

\section{1 .1 断面積}

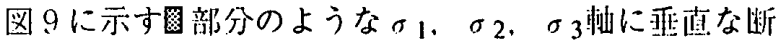
面の断面積を各々 $\mathrm{dS}_{1}(\mathrm{r}, \mathrm{z}), \mathrm{dS}_{2}(\mathrm{r}, \mathrm{z}), \mathrm{dS}_{3}(\mathrm{r}, \mathrm{z})$ と し. 以下の式 $(8)(9)(10)$ を用いて算出する。

$$
\begin{aligned}
& \mathrm{dS}_{1}(\mathrm{r}, \mathrm{z})=2 \mathrm{~J}(\mathrm{r}, \mathrm{z}) \sec \phi(\mathrm{r}, \mathrm{z}) \mathrm{dz} d \theta \\
& \mathrm{dS}_{2}(\mathrm{r}, \mathrm{z})=4 \frac{\partial}{\partial \mathrm{r}} \mathrm{J}(\mathrm{r}, \mathrm{z}) \mathrm{dr} \mathrm{dz}
\end{aligned}
$$

$$
\mathrm{dS}_{3}(\mathrm{r}, \mathrm{z})=2 \mathrm{~J}(\mathrm{r}, \mathrm{z}) \frac{\partial}{\partial \mathrm{r}} \mathrm{J}(\mathrm{r}, \mathrm{z}) \cos \phi(\mathrm{r}, \mathrm{z}) \mathrm{dr} \mathrm{d} \theta
$$

\section{1 .2 微小立体の表面に㗢く力}

図 10(b) (c) に示す様な微小立体の $\mathrm{dS}_{1}(\mathrm{r} \pm \mathrm{dr}, \mathrm{z})$ 平面 に㑬く力, $\mathrm{dF}_{1}(\mathrm{r} \pm \mathrm{dr}, \mathrm{z})$ は式（11）により得られる。 $\mathrm{dF}_{1}(\mathrm{r} \pm \mathrm{dr}, \mathrm{z})=\sigma_{1}(\mathrm{r} \pm \mathrm{dr}, \mathrm{z}) \mathrm{dS}_{1}(\mathrm{r} \pm \mathrm{dr}, \mathrm{z})$

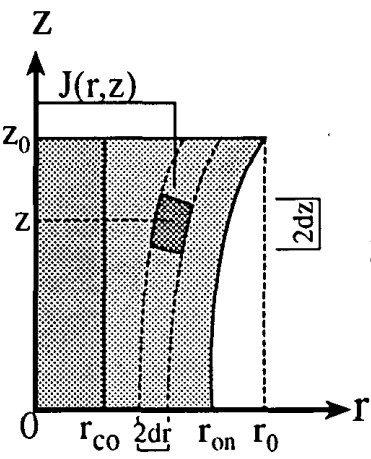

(a) 位置

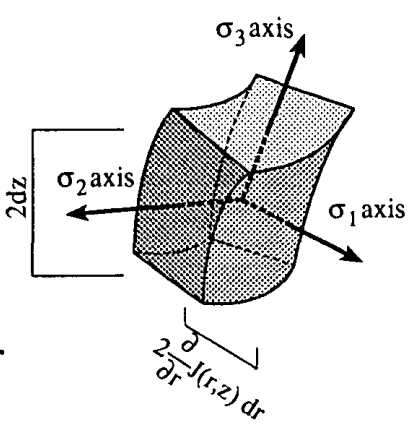

(b) 概略図

図8 微小立体

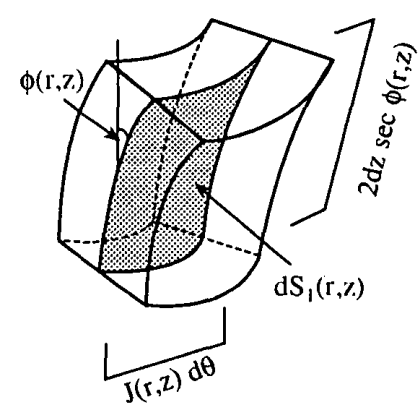

(a) $\sigma_{1}$ に垂直な断面

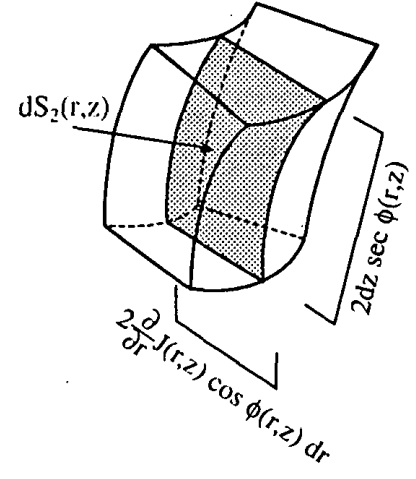

(b) $\sigma_{2}$ に垂直な断面

図 9 微小立体の断面皘

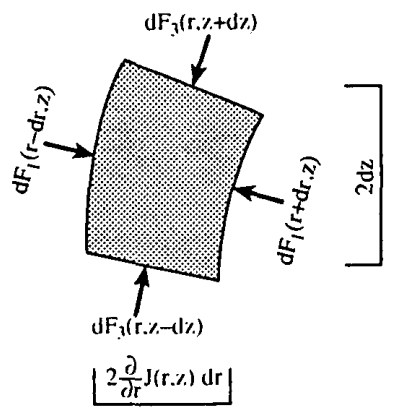

(b) $\sigma_{2}$ に垂直な断面

図10 微小立体の面に加わる力

四10 微立体の面に加わる力

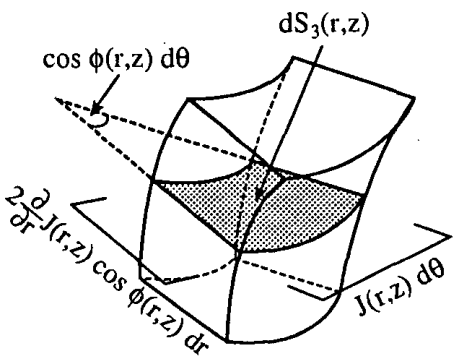

(c) $\sigma_{3}$ に垂直な断面

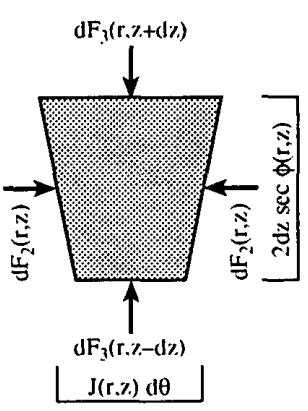

(a) $\sigma$, に垂直な断面 
また，図10(a) (c) に示す様な微小立体の $\mathrm{dS}_{2}(r, z)$ 平而に 働く力. $\mathrm{dF}_{2}(\mathrm{r}, \mathrm{z})$ は以下の式（12）により得られる。

$$
\mathrm{dF}_{2}(\mathrm{r}, \mathrm{z})=\sigma_{2}(\mathrm{r}, \mathrm{z}) \mathrm{dS}_{2}(\mathrm{r}, \mathrm{z})
$$

そして，図10(a) (b)に示す椂な微小立体の $d S_{3}(r, z \pm d z)$ 平面に働く力, $\mathrm{dF}_{3}(\mathrm{r}, \mathrm{z} \pm \mathrm{dz})$ は以下の式（13）により得 られる。

$$
\mathrm{dF}_{3}(\mathrm{r}, \mathrm{z} \pm \mathrm{dz})=\sigma_{3}(\mathrm{r}, \mathrm{z} \pm \mathrm{dz}) \mathrm{dS}_{3}(\mathrm{r}, \mathrm{z} \pm \mathrm{dz})
$$

\section{1 .3 仮想物体力}

ここで，压㜊忍力鞋内部の全ての微小立你についての 釣合条件を考えてみる。本解析方法では主灾力の方向と その大きさを前述したように関数式(2)〜(7)を用いて仮定 しているため，全ての位置での微小立休における制合条 件を満たすような保数 $\alpha_{1} 、 \alpha_{2}$ は存在しない。そこで、 图12(b)(c)よりの、刺方向の釣合に必要な力 $\mathrm{Bf}$ ，を式(14) で、また図12(a)(c)より。檕方向の必要なう $\mathrm{Bf}_{3}$ を式(15) で定義する。（但し、の2軦方向は常に徐り合うのでこの ような力は必要としない。）そして図11に示すようにこ れらの力を成分とする力をBfとする。以徯。この力Bfを 仮想物体力と称する。

$$
\begin{aligned}
& B f_{1}(r, z) d r d z d \theta=\left\{d F_{1}(r-d r, z)-d F_{1}(r+d r, z)\right\} \\
& +\left\{d F_{2}(r, z) \cos \phi(r, z) d \theta\right\} \\
& +\left\{d F_{3}(r, z-d z)+d F_{3}(r, z+d z)\right\} \frac{\partial^{2}}{\partial z^{2}} J(r, z) d z
\end{aligned}
$$

$$
B f_{3}(r, z) d r d z d \theta
$$

$$
\begin{aligned}
& =\left\{d F_{1}(r-d r, z)+d F_{1}(r+d r, z)\right\} \frac{\partial^{2}}{\partial r \partial z} J(r, z) d r \\
& +\left\{d F_{3}(r, z-d z)-d F_{3}(r, z+d z)\right\}
\end{aligned}
$$

\section{1 .4 主応力関数の決定}

前述した仮想物体力による䛊淕Erを以下の式（16）で 定義する。

$$
\mathrm{Er}=\iiint\left\{\mathrm{Bf}_{1}(\mathrm{r}, \mathrm{z})^{2}+\mathrm{Bf}_{3}(\mathrm{r}, \mathrm{z})^{2}\right\} \mathrm{dr} \mathrm{dz} \mathrm{d} \theta
$$

この誤养Erが最小となるように，先に仮完した主心力阙 数の倸数 $\alpha_{1}$ と $\alpha_{2}$ を以下の侢微分方程式(17) (18) を解くこ とにより氿完する。

$$
\begin{aligned}
& \frac{\partial}{\partial \alpha_{1}} \operatorname{Er}=0 \\
& \frac{\partial}{\partial \alpha_{2}} \operatorname{Er}=0
\end{aligned}
$$

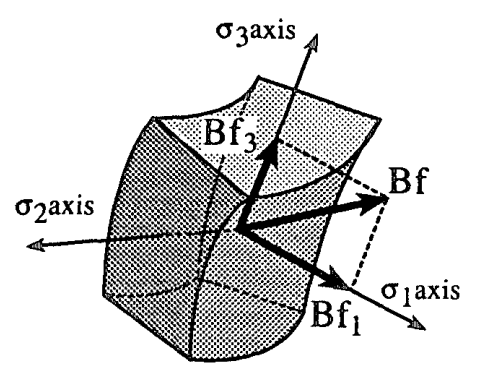

図11 仮想物体力

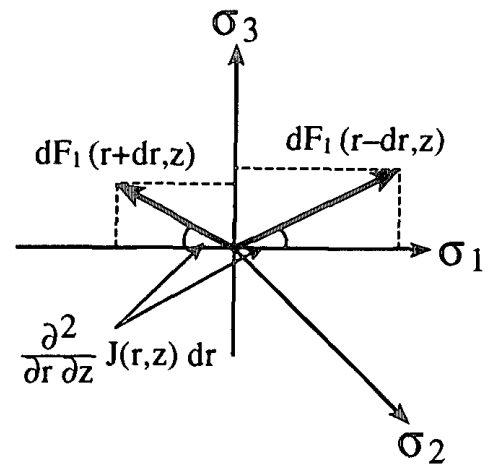

(a) 0,に垂直な断面

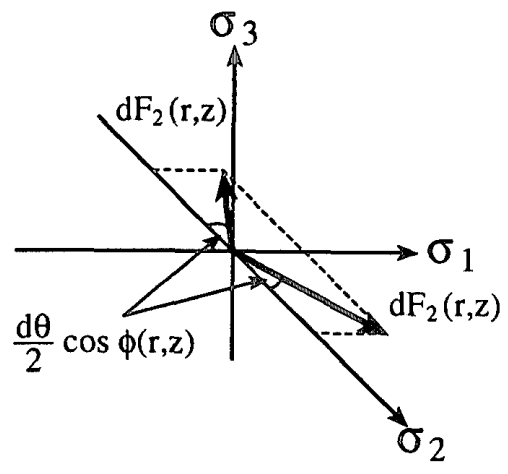

(b) $\sigma_{2}$ に垂直な断面

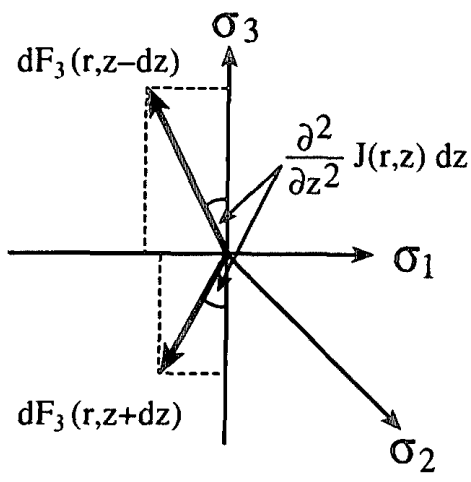

(c) $\sigma_{3}$ に垂直な断面

図12 微小立体表面に加わるカの示力図 


\section{2 压禖灾力場の汰定}

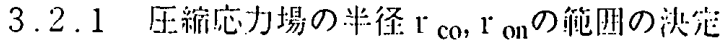

図13に示す様な $z=z_{0}$ の微小断而におけるせん断灾力 $\tau(r)$ は式（19）により得られる。

$$
\tau(\mathrm{r})=\left\{\sigma_{3}\left(\mathrm{r}, \mathrm{z}_{0}\right)-\sigma_{1}\left(\mathrm{r}, \mathrm{z}_{0}\right)\right\} \sin \phi\left(\mathrm{r}, \mathrm{z}_{0}\right) \cos \phi\left(\mathrm{r}, \mathrm{z}_{0}\right)
$$

図13の微小断而皘 $\mathrm{dA}_{\mathrm{c}}(\mathrm{r}) \mathrm{dr}$ は式（20）で得られる。

$$
d A_{c}(r) d r=J\left(r, z_{0}\right) \frac{\partial}{\partial r} J\left(r, z_{0}\right) d r d \theta
$$

前述のせん断応力こ(ケ)によりフープ渻には図14に示す ような分布力 $\mathrm{Q}$ が扣わる。この $\mathrm{Q}$ は以下のような式 (21)で得られる。

$$
Q d \theta=\int_{0}^{r_{0}} \tau(r) d A_{c}(r) d r
$$

フープ筋の釣合条件を考意すると、フープ筋の応力の S1 は以下の式（22）で得られる。

$$
\sigma_{s 1}=\frac{4}{s D \rho_{s}} \int_{0}^{\pi} Q \sin \theta d \theta=\frac{8 Q}{s D \rho_{s}}
$$

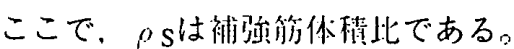

しかし、フープ篧による拘束力が仮想物体力により渦

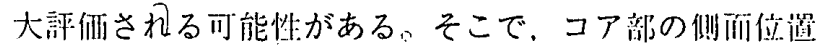
での拘柬力を漟虑することにより。この場命のフープ符 の応力 $\sigma$ S2 は以下の式（23）で得られる。

$$
\sigma_{s 2}=\frac{\sigma_{1}\left(r_{c o}, z\right)}{2 \rho_{s}}
$$

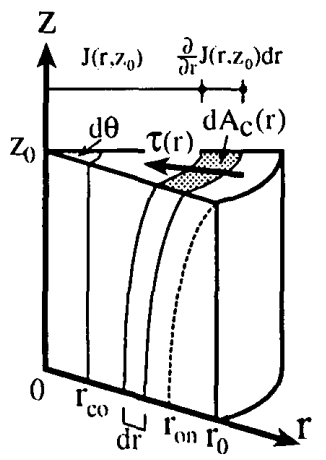

図13 せん断応力

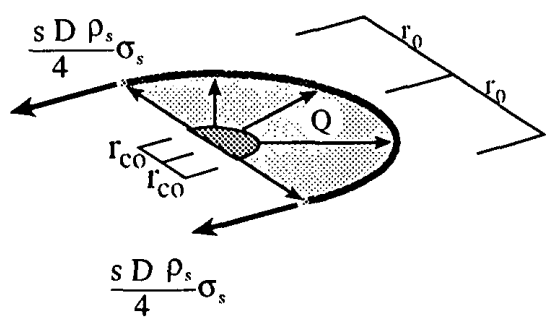

図14 フープ筋位置での釣合
以上により得られた $\sigma \mathrm{S}_{1}$ と $\sigma \mathrm{s} 2$ のいずれか大きい方を

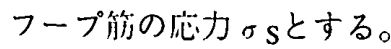

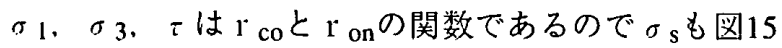
に示すような $\mathrm{r}$ coと $\mathrm{r}$ on の関数となる。一方，。 $\sigma_{\mathrm{s}}$ は式

(24) に示す様にフープ筋の降伏応力 $\sigma$ y以下でなければ ならない。

$$
0 \leq \sigma_{\mathrm{s}} \leq \sigma_{\mathrm{y}}
$$

この式（24）より，図15の圈部で示すような $r_{c o}$ と $r_{\text {on }}$ の 新突笓四が得られる。

\section{2 .2 一軘压縮強度 $\sigma \mathrm{cc}$ の決定}

ある $r_{c o}$ と $r_{\text {on }}$ での，座標 $(\mathrm{J}(\mathrm{r}, \mathrm{z}), \mathrm{z})$ における軸 応力 $\sigma_{z}(r, z)$ は以下の式（25）により得られる。

$$
\sigma_{\mathrm{z}}(\mathrm{r}, \mathrm{z})=\sigma_{1}(\mathrm{r}, \mathrm{z}) \sin \phi^{2}(\mathrm{r}, \mathrm{z})+\sigma_{3}(\mathrm{r}, \mathrm{z}) \cos \phi^{2}(\mathrm{r}, \mathrm{z})
$$

この粗応力 $\sigma_{\mathrm{z}}$ を用いることにより $\mathrm{z}=z_{0}$ 面での平均応力 のはは以下の式（26）により得られる。

$$
\sigma_{0}=\frac{2}{r_{0}^{2}} \int_{0}^{r_{0}} \sigma_{z}(r, z) d A_{c}(r) d r
$$

ここで $\sigma_{\mathrm{z}}$ が $\mathrm{r}_{\mathrm{co}}$ と $\mathrm{r}_{\mathrm{on}}$ の関数であることから， $\sigma_{0}$ も図 14 に示すような $\mathrm{r}_{\mathrm{co}}$ と $\mathrm{r}$ on の関数となる。そこで下界定理に より，図16の圈部で示すような前述した $\mathrm{r}_{\mathrm{co}}$ と $\mathrm{r}_{\text {on }}$ の許容 箱四内での $\sigma_{0}$ の最大值 $\sigma \mathrm{cc}$ を拘束されたコンクリート円 杖:の一刺区䋨強度とする。

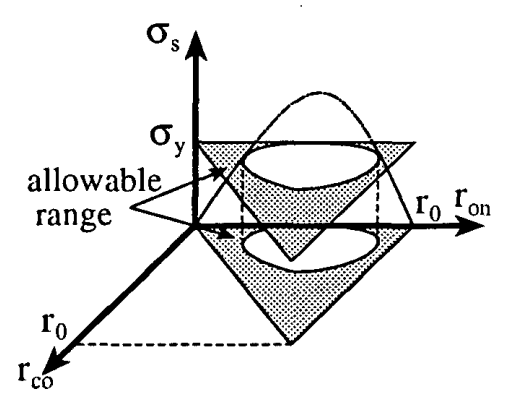

図15 フープ筋応力 $\sigma_{\mathrm{s}}$ と許容範囲

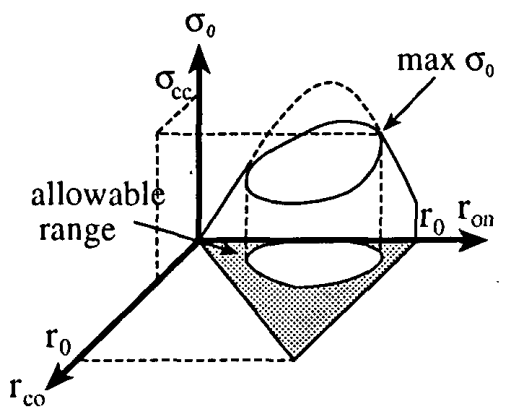

図16 平均応力 $\sigma_{0}$ と許容範囲 


\section{4. 解析結果}

\section{1 解析条件}

解析パラメータとして、 s / D (補強篎間隔/コンク リート円柱の直径) と $\rho_{\mathrm{s}} \sigma_{\mathrm{y}} / \sigma_{\mathrm{B}}$ (補弦筋体皘比 $\times$ 補㧧

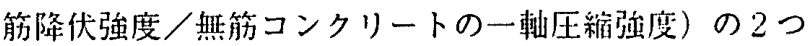
を用いて解析を行った。また、鈴木・中塚らの実娩を解 析対象とし， $d_{s}=9 / 150$ とした。本論文において以该 $\mathrm{s} /$ $\mathrm{D}$ を“補強筋間隔比”， $\rho_{\mathrm{s}} \sigma_{\mathrm{s}}$ を“拘束応力”， $\sigma_{\mathrm{cc}} / \sigma$ Bを“拘束効果”と称する。

\section{2 解析絬果}

図17に拘束応力と補強筋間隔比の関係の解析絬果を太 線で示す。また同図に鈴木・中塚らの㬰験結果いより得ら れた補強筋が降伏する筙用を圈で示す。拘束応力は図17に 示すように、補強筋間隔比の小さい場合は一定の値つま り補強筋降伏時の拘束応力の値をとる。しかし、補強筋 間隔比が大きい場合は拘束応力は補強筋間隔比の增加に 徥い減少して行く。そして，全ての $\rho_{\mathrm{s}} \sigma_{\mathrm{y}} / \sigma_{\mathrm{B}}$ で同じ值 になる。これは補強笳間隔比の小さい場合は補強筋が降 伏する範囲で拘束効果が最大となり，補強筋閒掘比の大 きい場合は補強筋が降伏しない範囲で拘束効果が最大と なることを示している。また，解析結果と実娩佔の降候

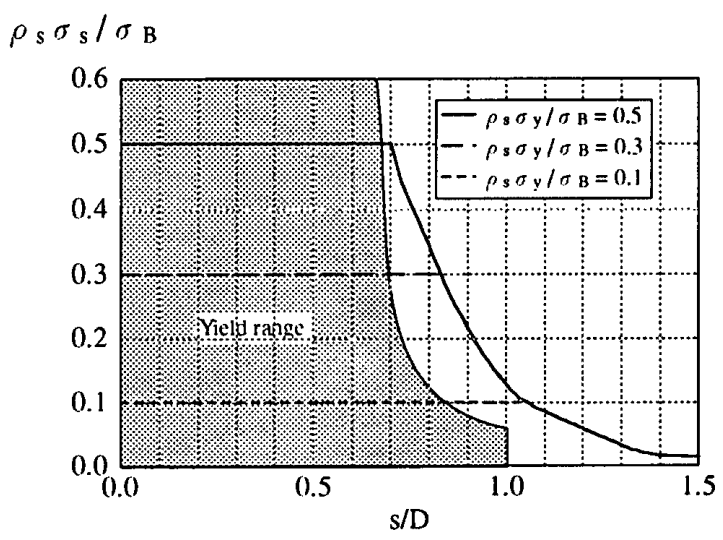

図17 拘束忍力と補強筋間隔比の関係

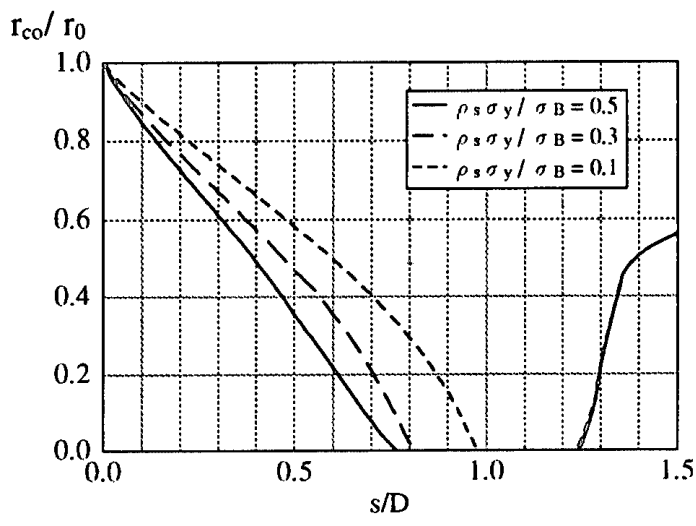

図18 コア部の半径と補強筋間隔比の関係
範四を比較してみると， $\rho_{\mathrm{s}} \sigma_{\mathrm{y}} / \sigma_{\mathrm{B}}$ の值によって多少の ズレがあるもののほぼ対応していることがわかる。

図 18 にコア部の半径 $\mathrm{r}_{\mathrm{co}}$ と補強筋間隔比の関係を示 す。同図において，r coは補強筋間隔比が増加するに徉 い单調減少し0となり，その後単調増加する。また， ${ }_{\mathrm{s}} \sigma_{\mathrm{y}} / \sigma_{\mathrm{B}}$ が大きいものほど, $r_{\mathrm{co}}$ は小さい值をとる。

図19にオ二オン部の半径 $\mathrm{r}$ on と補強筋間隔比の関係を 示す。同図において，ron は補強笳間隔が小さい場合は 単調減少するが，r coが0になった後に単調増加に転ず る。また, $\rho_{\mathrm{s}} \sigma_{\mathrm{y}} / \sigma_{\mathrm{B}}$ で比較した場合, $\rho_{\mathrm{s}} \sigma_{\mathrm{y}} / \sigma_{\mathrm{B}}$ が大 きいものほど $\mathrm{r}_{\text {on }}$ は小さい值を取る。しかし，前述した ように拘束応力は補強筋間隔比がある值を超えると同じ 䛧をとる。これに対応して $r$ on の值も補強筋間隔比がそ の值を超えると同じ值になる。

図20に拘束効果 $\sigma_{\mathrm{cc}} / \sigma_{\mathrm{B}}$ と補強筋間隔比の関係の解析 絬果と鈴木 - 中塚らの実験結果 $\left(\sigma_{\mathrm{B}}=330 \mathrm{~kg} / \mathrm{cm}^{2}\right)$ を示 す。拘束効果は図20に示すように補強筋間隔比の増加に 㴚い単調減少する。そして，r on 場合と同様に拘束応 力に対応して補強筋間隔比がある值を超えると同じ値に なる。つまり、補強筋比と降伏応力の拘束効果に対する 影翌の頙打ちが見られる。また, 解析結果と奏騃値を比 较すると、補強筋間隔比 $\mathrm{s} / \mathrm{D} か ゙$ 小さい場合，解析值が実験

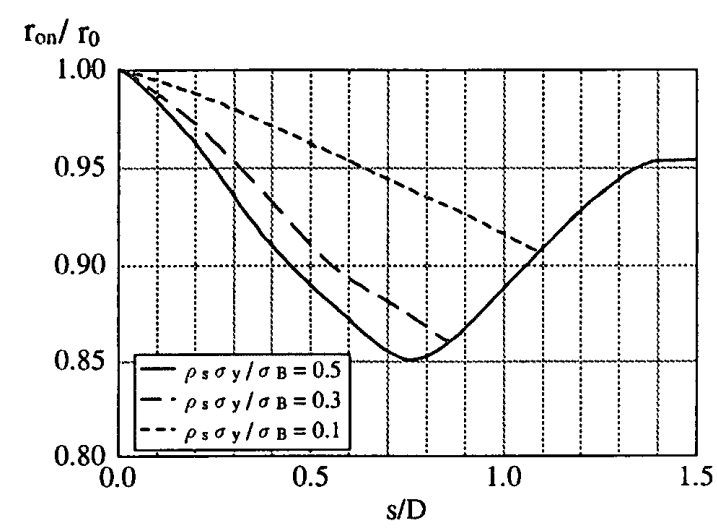

図19才ニオン部の半径と補強筋間隔の関係

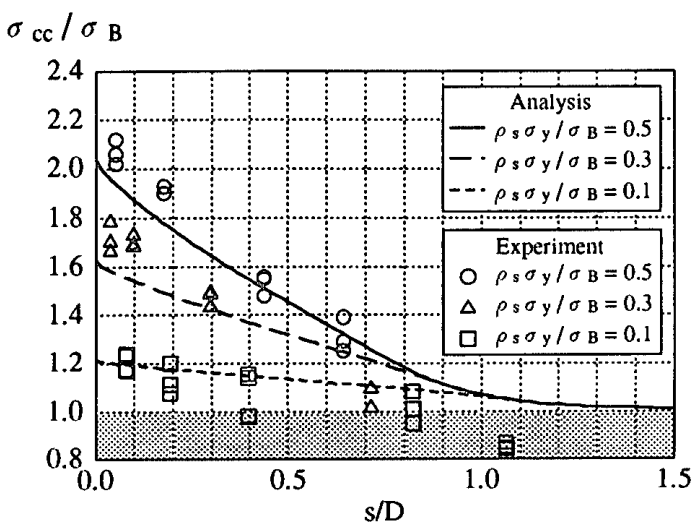

図20＼cjkstart拘束効果と補強筋間隔の関係 
值に比べやや低い値を示しているが, 全体的によく対応 している。

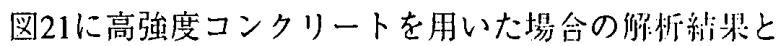
実験結果（ $\sigma_{\mathrm{B}}=680 \mathrm{~kg} / \mathrm{cm}^{2} ）$ を示す。この図に示すように 高強度コンクリートの場合でも普通強度の埸合と同棑全 体的によく刘応している。

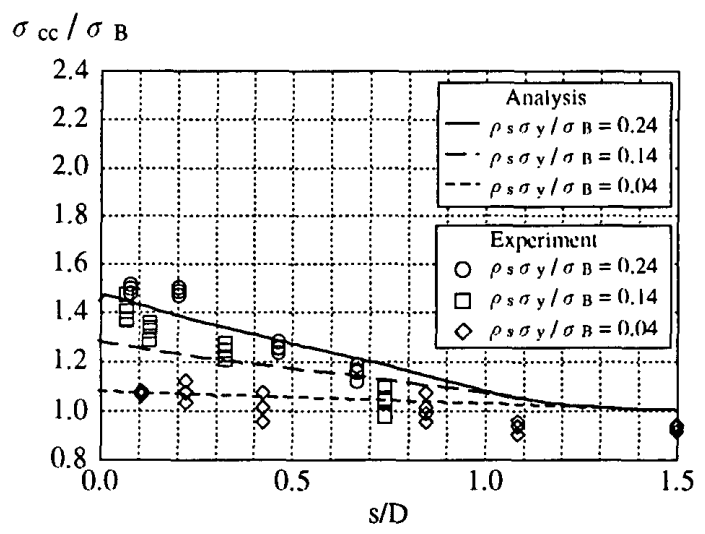

図21拘束効果と補強筋間隔の関係（高強度）

\section{5. 結論}

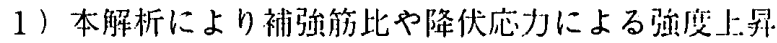
への影鲟の頭打ち現象を表すことができる。

2）実験值と解析㑭を比較した場合，雨者は比較的よ い対応を示す。

3）生編応力場と破填条件を仮完することにより，四 形フープ䈈による拘束效果を下界定理を用いて算穴するる ことができる。

\section{謝辞}

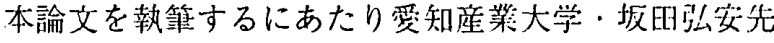
生から御助言。御指導を睗りました。また，大阪大学・ 中塚佶先生から貴重な奏娩データを送っていただきまし た。ここに記して謝意を表します。

\section{参考文献}

1) 鈴木計夫, 中塚佶, 井上和正: 円形補強筋を川いたコン ファインドコンクリートの応力・歪み特性及び同コンク リート内に配筋さ机た压䋨帆筋の座屈性状，コンクリート 構造物の䩗性とその訣休法に関するコロキウム，日本コン クリート工学協会, pp. 21-32, 1988.3

2) Shamim A. Sheikh and Mural T. Toklucu: Rcinforced Concrelc Coulums Confined by Circular Spirals and Hoops, $\mathrm{ACI}$ Structural Journal, Vol. 90 No. 5, pp. 542-553, 1993

3 ) Richart. F. E. : Study of the Failure of Concrete under Combined
Compressive Stresses, University of Illinois Engineering Experimental Station, Bulletin, No. 185. 104 pp. 1928

\section{付録 1 （フープ筋付近の圧縮応力場）}

压緛応力場のモデル化（本論.2２２仮定 2 ：圧縮応力場の

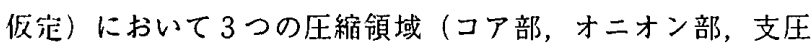

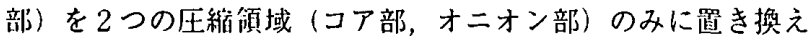
て解析をおこなった。ここではその詳細について述べる。

本諭で述べたように，付図 1 (本諭 2.2 ，仮定 $2 ：$ 生縮心力 場の図 3 の詳細図）に示すような圧縮応力場が形成されるとす る。具体的には支圧部の応力場は付図 2 の様になる。この場合 E F 断面の境界条件（せん断応力が0となる。）を満たすよう にフープ筋の拘束力により支圧部内で応力の流机が変化する。 しかし，この応力場モデルを用いた場合，主応力の仮定がかな り䙓雑なものとなる。そのため本解析方法ではこの圧縮応力場 モデルを支圧部を用いない付図 3 に示すようなモデルを用いて 解析を行う。この場合, フープ筋の拘束力を E F 断面での釣台 条件を満たすようにせん断力に置き換えることにより 3 つの領 域を用いた解析と同様の結果を得られる。

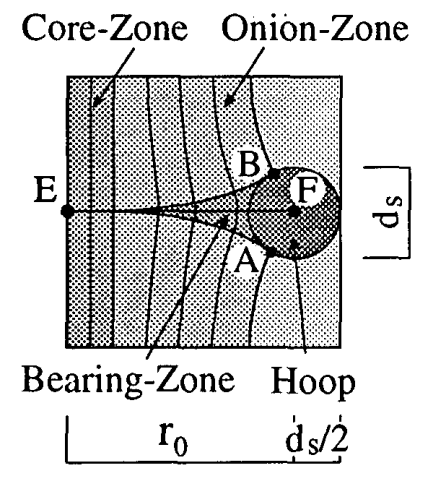

付図 1 圧縮応力場詳細図

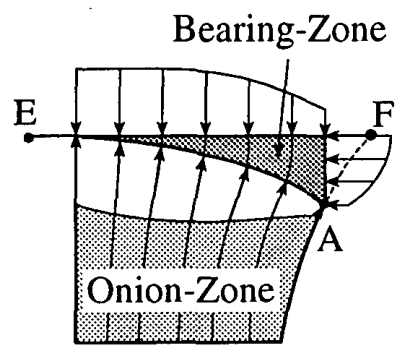

付図2 応力分布図（支圧部有り）

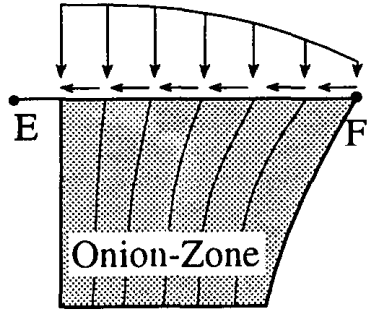

付図 3 応力分布図（支圧部無し） 


\section{付録 2 （誤差による影響）}

本論文では，圧縮応力場の釣合条件を満たすためため仮想物 体力Btを想定し解析を行った。そのために䛊差Erが非じた。こ こでは，その誤差による影㫼について考察を行う。

付図 $4 ， 5$ にある条件下 $\left(\sigma_{\mathrm{B}}=330 \mathrm{kgf} / \mathrm{cm}^{2}, \rho_{\mathrm{s}} \sigma_{\mathrm{y}} / \sigma\right.$ $\mathrm{B}=0.5, \mathrm{~s} / \mathrm{D}=0.4$ ) での仮想物体力 $\mathrm{Bf}$ の $\mathrm{r}$ 軸方向成分 $\mathrm{B} \mathrm{f}_{\mathrm{r}}$ と $z$ 槙 方向成分 $\mathrm{Bf}_{z}$ の分在を示す $\left(\mathrm{Bf}_{\mathrm{r}}\right.$ は $\mathrm{r}$ 軸方向を， $\mathrm{Bf}_{z}$ は $\mathrm{z}$ 輣方问を 正とする）。付圆 4，5に示すように， $\mathrm{Bf}_{\mathrm{r}}$ とBf 的に分布している。つまり，釣合状態と比較した場合にフーブ 筋による拘束力や軸圧維力は位置により多少異なることがわか る。

ここでこれらの仮想物体力による誤差をより把握するため に，付図 6 に同条件下の解析における第 3 主応力の軌䟢による 切断面位置での拘束力の分布を，また付図 $7 に z$ 檕方们の排來 効果の分布を示す。付图 6 に示すように拘束力も仮想物休为の 影㸷のため位置により巽なり，最大 7 \%の誤差を生ずる。ま
た，拘束効果も付図 7 に示すように，解析值として用いた値 （図中穴です $Z=Z_{0}$ での值）が最大となる放物線状の分布を 示し，最大 $4 \%$ の誤差を生ずる。

ここではある特定の条件下での解析結果を示したが他の条件 下での解析もほほ同様の傾向を示している。

以上のように仮想物体力による誤差の個々の影每について述 ベてきたが、ここで全体的に把握するために式（16）で得られ る誤差Erを用いて仮想物体力による影響BErを以下の式（27） で定義する。

$$
\mathrm{BEr}=\frac{\sqrt{\mathrm{Er}}}{\sigma_{\mathrm{B}} \pi \mathrm{r}_{0}^{2}}
$$

付図 8 にBErと補強筋間餇比の関係を示す。この図に示すよ うに補強筋比や降伏応力や補强筋間隔によりその值は多少恋化 する。しかし，全て1％も満たない值となる。この事から仮想 物体力による影幚は全体としては許容範囲内であるといえる。

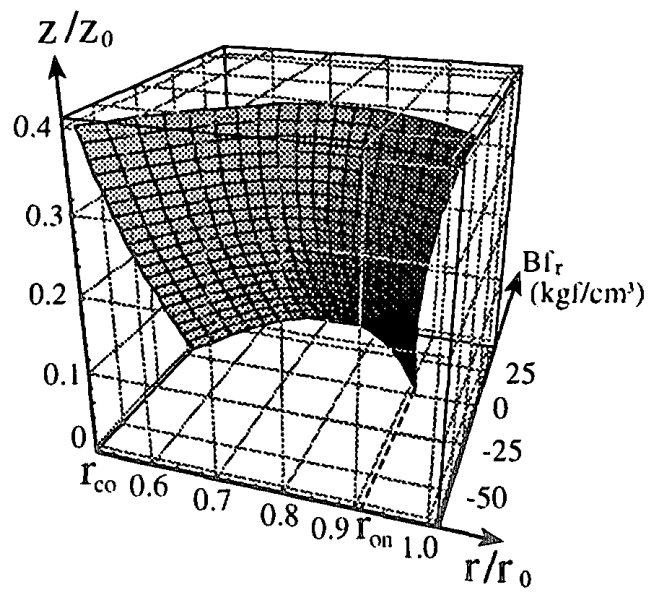

付図 $4 \mathrm{r}$ 軸方向の仮想物体力

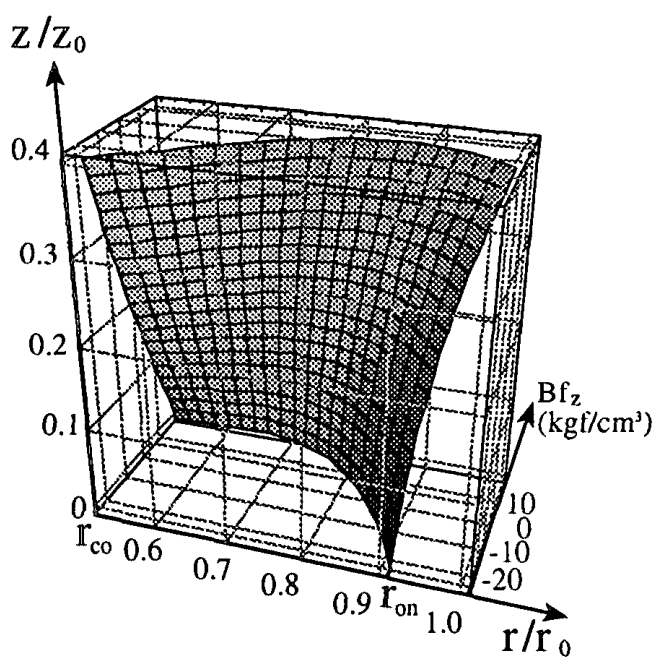

付図 $5 \mathrm{z}$ 軸方向の仮想物体力

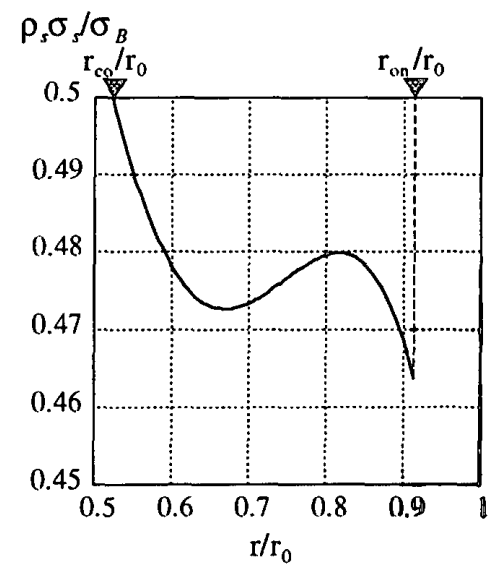

付図 6 フープ筋の拘束力の分布

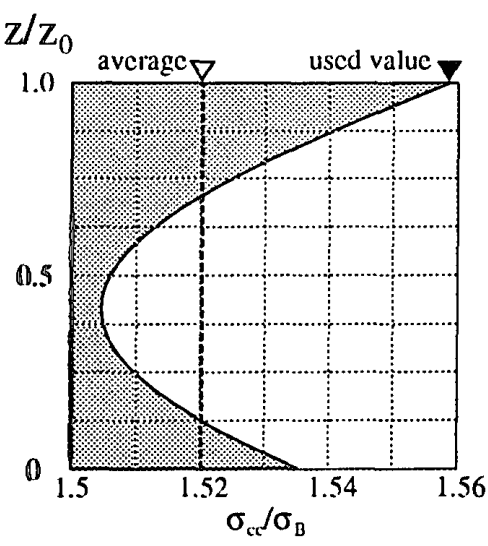

付図 7 拘束効果の分布

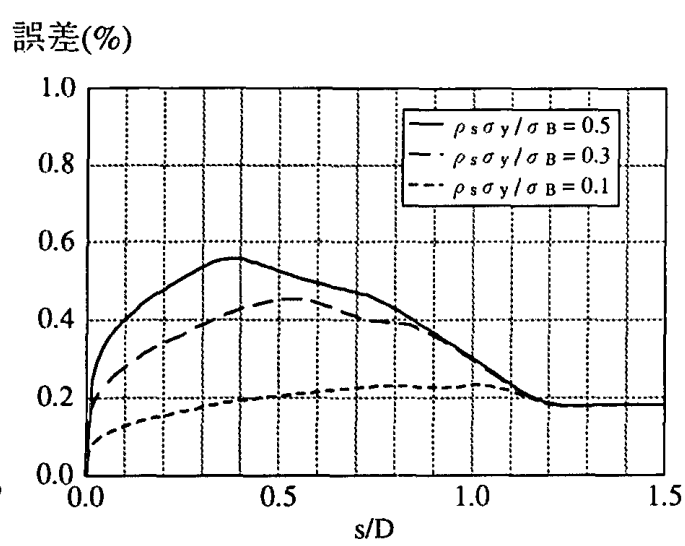

付図 8 誤差の分布

（1994年12月10日原稿受理，1995年 6 月22日採用決定） 